\title{
In vitro Effect of Silver Nanoparticles on Creatine Kinase Activity
}

\author{
Marcos Marques da Silva Paula, ${ }^{*}$, Cláudio Sérgio da Costa, ${ }^{a}$ Mario César Baldin, ${ }^{a}$ \\ Giselli Scaini, ${ }^{b}$ Gislaine Tezza Rezin, ${ }^{b}$ Karen Segala, ${ }^{c}$ Vanessa Moraes de Andrade, ${ }^{d}$ \\ César Vitório Franco ${ }^{c}$ and Emilio Luiz Streck ${ }^{b}$
}

\author{
${ }^{a}$ Laboratório de Síntese de Complexos Multifuncionais, Programa de Pós-graduação em Ciências da Saúde, \\ Universidade do Extremo Sul Catarinense, 88806-000 Criciúma-SC, Brazil \\ ${ }^{b}$ Laboratório de Fisiopatologia Experimental, Programa de Pós-graduação em Ciências da Saúde, \\ Universidade do Extremo Sul Catarinense, 88806-000 Criciúma-SC, Brazil \\ 'Departamento de Química, Universidade Federal de Santa Catarina, 88040-900 Florianópolis-SC, Brazil \\ ${ }^{d}$ Laboratório de Imunologia e Mutagênese, Programa de Pós-graduação em Ciências da Saúde, \\ Universidade do Extremo Sul Catarinense, 88806-000 Criciúma-SC, Brazil
}

\begin{abstract}
A nanopartícula de prata $(\mathrm{AgN})$ é um dos mais proeminentes nanoprodutos, uma vez que a prata exibe propriedades físicas, químicas e biológicas notavelmente incomuns. Creatina quinase (CK) desempenha um papel central no metabolismo de tecidos que consomem muita energia, tais como o cérebro, músculo esquelético e coração, funcionando como um efetivo sistema tampão dos níveis de ATP celular. Uma diminuição na atividade da CK pode alterar a homeostase energética, contribuindo para a morte celular. No presente trabalho nós estudamos o efeito in vitro de $\mathrm{AgN}$ na atividade da $\mathrm{CK}$ de cérebro, coração e músculo esquelético de ratos. Nossos resultados demonstraram que $\mathrm{AgN}\left(10,25\right.$ e $\left.50 \mathrm{mg} \mathrm{L}^{-1}\right)$ in vitro inibiram a atividade da CK em cérebro e músculo esquelético, porém não em coração. Vários trabalhos mostraram que os efeitos citotóxicos da $\mathrm{AgN}$ provavelmente envolvem a interação entre íons prata e grupos sulfidrila de proteínas. Nós sugerimos que a $\mathrm{AgN}$ inibiu a atividade da $\mathrm{CK}$ por meio da interação com grupos tiol da enzima.
\end{abstract}

One of the most prominent nanoproducts is the silver nanoparticle $(\mathrm{AgN})$, since silver ions exhibit remarkably unusual physical, chemical and biological properties. Creatine kinase (CK) plays a central role in metabolism of high-energy consuming tissues such as brain, skeletal muscle and heart, where it functions as an effective buffering system of cellular ATP levels. A decrease of CK activity may impair energy homeostasis, contributing to cell death. In the present work we studied the in vitro effect of $\mathrm{AgN}$ on the activity of $\mathrm{CK}$ from rat brain, heart and skeletal muscle. Our results demonstrated that $\mathrm{AgN}\left(10,25\right.$ and $\left.50 \mathrm{mg} \mathrm{L}^{-1}\right)$ in vitro inhibited CK from brain and skeletal muscle, but not from heart. Several works showed that AgN cytotoxic effects probably involve interaction between silver ions and sulphydryl groups of proteins. We suggest that AgN inhibited CK activity through interactions with thiol groups of the enzyme.

Keywords: silver nanoparticles, creatine kinase, brain, heart, skeletal muscle

\section{Introduction}

Medicinal inorganic chemistry is a discipline of growing significance in both therapeutic and diagnostic medicine. Inorganic compounds have been used in medicine in an empirical way with little attempt to design the compounds to be used. The design of new biologically active compounds involves the control of toxicity and the

*e-mail: mms@unesc.net target of the metal to specific tissues, organs, or cells. ${ }^{1}$ The current array of successful metallopharmaceuticals includes platinum anticancer drugs, radio diagnostic agents and others. ${ }^{2}$ Thus, biomedical inorganic chemistry offers the potential for the design of novel therapeutic and diagnostic agents and for the treatment and understanding of diseases. ${ }^{3}$

Nanotechnology involves the creation and manipulation of materials at nanoscale levels and is a promising field for generating new applications in medicine. ${ }^{4-8}$ One of the most prominent nanoproducts are silver nanoparticles 
$(\mathrm{AgN})$, since silver exhibits remarkably unusual physical, chemical and biological properties. ${ }^{9}$ Silver has been known in antiquity to be an antibacterial agent and was used in colloidal form in ointments in the end of the $19^{\text {th }}$ century. Still, the strong antimicrobial activity is a major direction for development of AgN products, ${ }^{10,11}$ including contraceptive devices, surgical instruments and bone protheses, all coated with AgN. ${ }^{12}$

In contact with human body, nanoparticles can undergo a series of processes like binding and reacting with proteins, phagocytosis, deposition, clearance and translocation. Moreover, nanoparticles can elicit a spectrum of tissue responses such as cell activation, generation of reactive oxygen species (ROS) and cell death. ${ }^{13-15}$ It was recently demonstrated that several cell lines exposed to AgN presented decreased function of mitochondria. ${ }^{14,16,17}$ However, the mechanisms underlying this effect are not yet elucidated, but probably involve interaction between silver ions and sulphydryl groups of proteins.

Creatine kinase (CK; E.C. 2.7.3.2) plays a central role in metabolism of high-energy consuming tissues such as brain, skeletal muscle and heart, where it functions as an effective buffering system of cellular adenosine triphosphate (ATP) levels. The enzyme catalyzes the reversible transfer of the phosphoryl group from phosphocreatine to adenosine diphosphate (ADP), regenerating ATP. It is believed that during excitation a 10 -fold increase of cellular turnover occurs, and that during these rapids changes the creatine/ phosphocreatine/CK system is necessary as an energy buffering system to avoid large fluctuations of cellular ATP/ ADP levels in excitable tissues. ${ }^{18-20}$ It is also known that a diminution of CK activity may potentially impair energy homeostasis, contributing to cell death. ${ }^{21-25}$

In this article we evaluated the in vitro effect of $\mathrm{AgN}$ on $\mathrm{CK}$ activity from brain, heart and skeletal muscle of rats.

\section{Experimental}

Synthesis of silver nanoparticles ( $\mathrm{AgN})$ in aqueous media

AgN was synthesized through a $0.01 \mathrm{~mol} \mathrm{~L}^{-1}$ equimolar solution of $\mathrm{AgNO}_{3}$ and sodium citrate; $\mathrm{NaBH}_{4}$ in ultra pure water was then added and the final solution was kept under vigorous stirring for $30 \mathrm{~min}$. This solution acquired a yellow-gray turbid aspect after the addition of $\mathrm{NaBH}_{4}$ and a colloidal suspension was formed. ${ }^{26,27}$

\section{Animals}

Adult and male Wistar rats (250-300 g) were obtained from Central Animal House of Universidade do Extremo
Sul Catarinense. They were caged in group of 5 with free access to food and water and were maintained on a $12 \mathrm{~h}$ light-dark cycle (lights on 7:00 am), at a temperature of $23 \pm 1{ }^{\circ} \mathrm{C}$.

\section{Tissue and homogenate preparation}

Brain, heart and skeletal muscle (quadriceps) were homogenized $(1: 10, \mathrm{~m} / \mathrm{v})$ in buffer, $\mathrm{pH} 7.4\left(250 \mathrm{mmol} \mathrm{L}^{-1}\right.$ sucrose, 2 mmol L-1 EDTA, $10 \mathrm{mmol} \mathrm{L}^{-1}$ Trizma base, $50 \mathrm{IU} \mathrm{mL} \mathrm{m}^{-1}$ heparin). The homogenates were centrifuged at $800 \times g$ for $10 \mathrm{~min}$ and the supernatants were separated. AgN was suspended in buffer and added to the incubation medium to final concentrations ranging from 10 to $50 \mathrm{mg} \mathrm{L}^{-1}$ and incubated at $37^{\circ} \mathrm{C}$ for $1 \mathrm{~h}$. The activity of $\mathrm{CK}$ was then measured. Protein content was determined by the method described by Lowry et al. ${ }^{28}$ using bovine serum albumin as standard.

\section{Creatine kinase (CK) activity assay}

CK activity was measured in brain homogenates pre-treated with $0.625 \mathrm{mmol} \mathrm{L}^{-1}$ lauryl maltoside. The reaction mixture consisted of $60 \mathrm{mmol} \mathrm{L}^{-1}$ Tris-HCl, $\mathrm{pH}$ 7.5, containing $7 \mathrm{mmol} \mathrm{L}^{-1}$ phosphocreatine, $9 \mathrm{mmol} \mathrm{L}^{-1}$ $\mathrm{MgSO}_{4}$ and approximately $0.4-1.2 \mu \mathrm{g}$ protein in a final volume of $100 \mu \mathrm{L}$. After $15 \mathrm{~min}$ of pre-incubation at $37^{\circ} \mathrm{C}$, the reaction was started by the addition of $0.3 \mu \mathrm{mol}$ of ADP plus $0.08 \mu \mathrm{mol}$ of reduced glutathione. The reaction was stopped after $10 \mathrm{~min}$ by the addition of $1 \mu \mathrm{mol}$ of $p$-hydroxymercurybenzoic acid. The creatine formed was estimated according to the colorimetric method of Hughes. ${ }^{29}$ The color was developed by the addition of $100 \mu \mathrm{L} 2 \% \alpha$-naphtol and $100 \mu \mathrm{L} 0.05 \%$ diacetyl in a final volume of $1 \mathrm{~mL}$ and read spectrophotometrically after $20 \mathrm{~min}$ at $540 \mathrm{~nm}$. Results were expressed as units $\mathrm{nmol} \mathrm{min}^{-1} \mathrm{mg}^{-1}$ protein.

\section{Statistical analysis}

Data were analyzed by one-way analysis of variance followed by the Tukey test when F was significant. All analyses were performed using the Statistical Package for Social Science (SPSS) software. Differences were considered significant when $\mathrm{p}<0.05$.

\section{Results and Discussion}

The UV-visible absorption spectrum of $\mathrm{AgN}$ in aqueous medium is displayed in Figure 1. A strong absorption peak at approximately $388 \mathrm{~nm}$ originates from the surface 
plasmon resonance absorption of AgN particles. The good symmetric absorption peak implies that the size distribution of the nanoparticles is narrow. The absorption spectrum of an aqueous solution of the nanoparticles can be visualized on Figure 1, which reveals a single band with maximum absorption at $388 \mathrm{~nm}$ that corresponds to the surface plasmon resonance band of spherical silver particles..$^{30,31}$

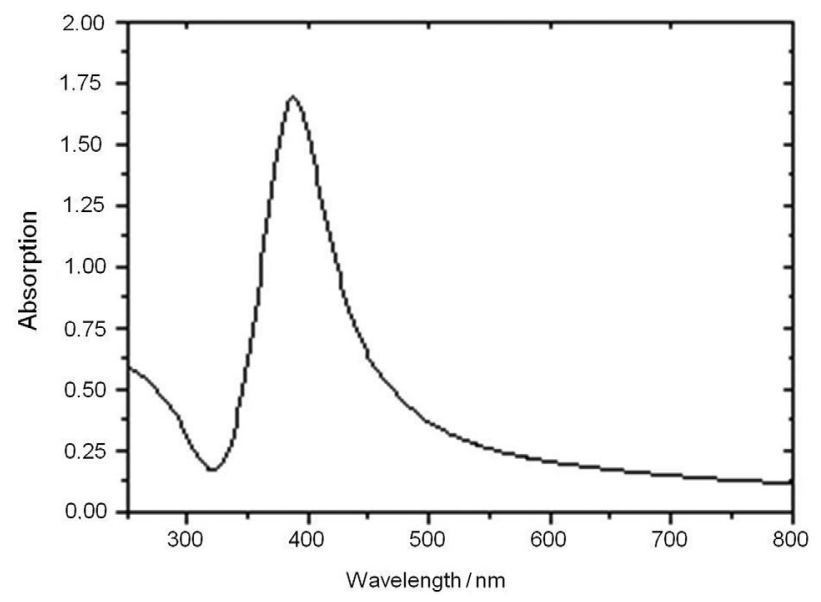

Figure 1. UV-visible spectrum of silver nanoparticles $(\mathrm{AgN})$ in aqueous medium.

Transmission electron microscopy (TEM) image of colloidal $\mathrm{AgN}$ revealed the presence of nearly spherical particles with diameters ranging from 5 to $45 \mathrm{~nm}$ and corroborates with data shown on recent publication (Figure 2). ${ }^{32}$ From the analysis of TEM micrographs it was selected the diameter of 600 randomly selected particles in enlarged TEM images with resulted in the particle size distribution histogram shown in Figure 2. The size distribution was found to be well described by a lognormal distribution function from which we obtained the media particles diameter of $19.7 \mathrm{~nm}$ and the distribution width of 0.48. A log normal distribution is widely used for describing the polydispersity of very small particles, where the lower metallic particle size is usually more difficult to measure and shows some aggregation and corroborates with data shown on recent publication. ${ }^{32}$

Figure 3 shows the in vitro effect of $\mathrm{AgN}$ on $\mathrm{CK}$ activity. As seen in Figure 3A, brain CK was significantly inhibited (35-40\%) by 10, 25 and $50 \mathrm{mg} \mathrm{L}^{-1} \mathrm{AgN}$. Figure 3B shows that skeletal muscle $\mathrm{CK}$ activity was also inhibited (35-55\%) by 10, 25 and $50 \mathrm{mg} \mathrm{L}^{-1} \mathrm{AgN}$. On the other hand, heart CK activity was not affected (Figure 3C).

CK is important for normal energy homeostasis by exerting several integrated functions, such as temporary energy buffering, metabolic capacity, energy transfer and metabolic control. The brain, heart and skeletal muscle are tissues with high and variable rates of ATP metabolism,

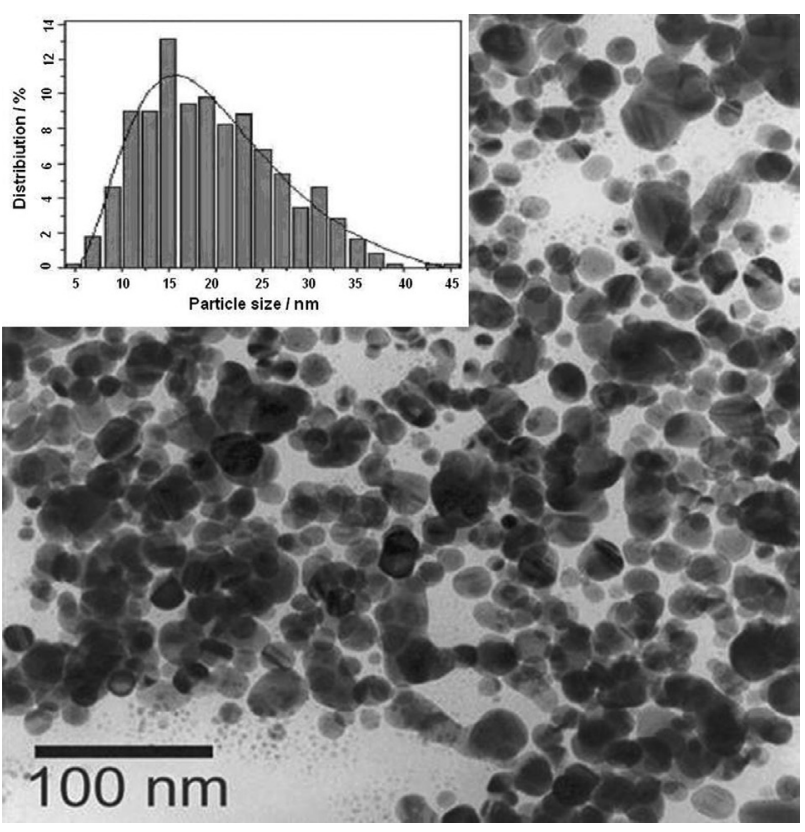

Figure 2. Transmission electron microscopy (TEM) image of silver nanoparticles $(\mathrm{AgN})$ synthesized in aqueous media.

have high phosphocreatine levels and CK activity. ${ }^{18-20}$ In the present work we demonstrated that CK from brain and skeletal muscle, but not from heart, was inhibited in vitro by $\operatorname{AgN}\left(10,25\right.$ and $\left.50 \mathrm{mg} \mathrm{L}^{-1}\right)$.

The CK molecule presents many cysteine residues in its structure. ${ }^{18-20}$ Sulphydryl groups of the enzyme can be a target for oxidation by nitric oxide and other free radicals leading to $\mathrm{CK}$ activity inhibition. ${ }^{33} \mathrm{Almofti}$ et al..$^{34}$ suggest that $\mathrm{AgN}$ seems to perturb mitochondria through interactions with thiol groups of the mitochondrial inner membrane. Several works also showed that $\mathrm{AgN}$ exert their antimicrobial effects through the interaction with proteins thiol groups. ${ }^{35-37}$ These works suggest that $\mathrm{AgN}$ may interact with proteins and enzymes with thiol groups within mammalian cells. ${ }^{38}$ Taking together these evidences and our present findings, it is tempting to speculate that $\mathrm{AgN}$ inhibited CK activity through interactions with thiol groups of the enzyme. The reason for specific inhibitory effect on brain and skeletal muscle CK are still not known. Most intriguing is the fact that the structure of CK in brain, skeletal muscle and heart is very similar (number of thiol groups). ${ }^{20}$

Our present findings are in accordance to other studies, which demonstrated impairment of metabolism caused by $\mathrm{AgN}^{39,40}$ Mitochondria seem to be sensitive target of toxic effects of $\mathrm{AgN}$. Besides metabolism impairment, it has been suggested that oxidative stress might also mediate the cytotoxicity of $\mathrm{AgN} .{ }^{39,40} \mathrm{AgN}$ may deplete antioxidant defense mechanism, which leads to oxidative stress. Damage to cell membranes appears to be another 

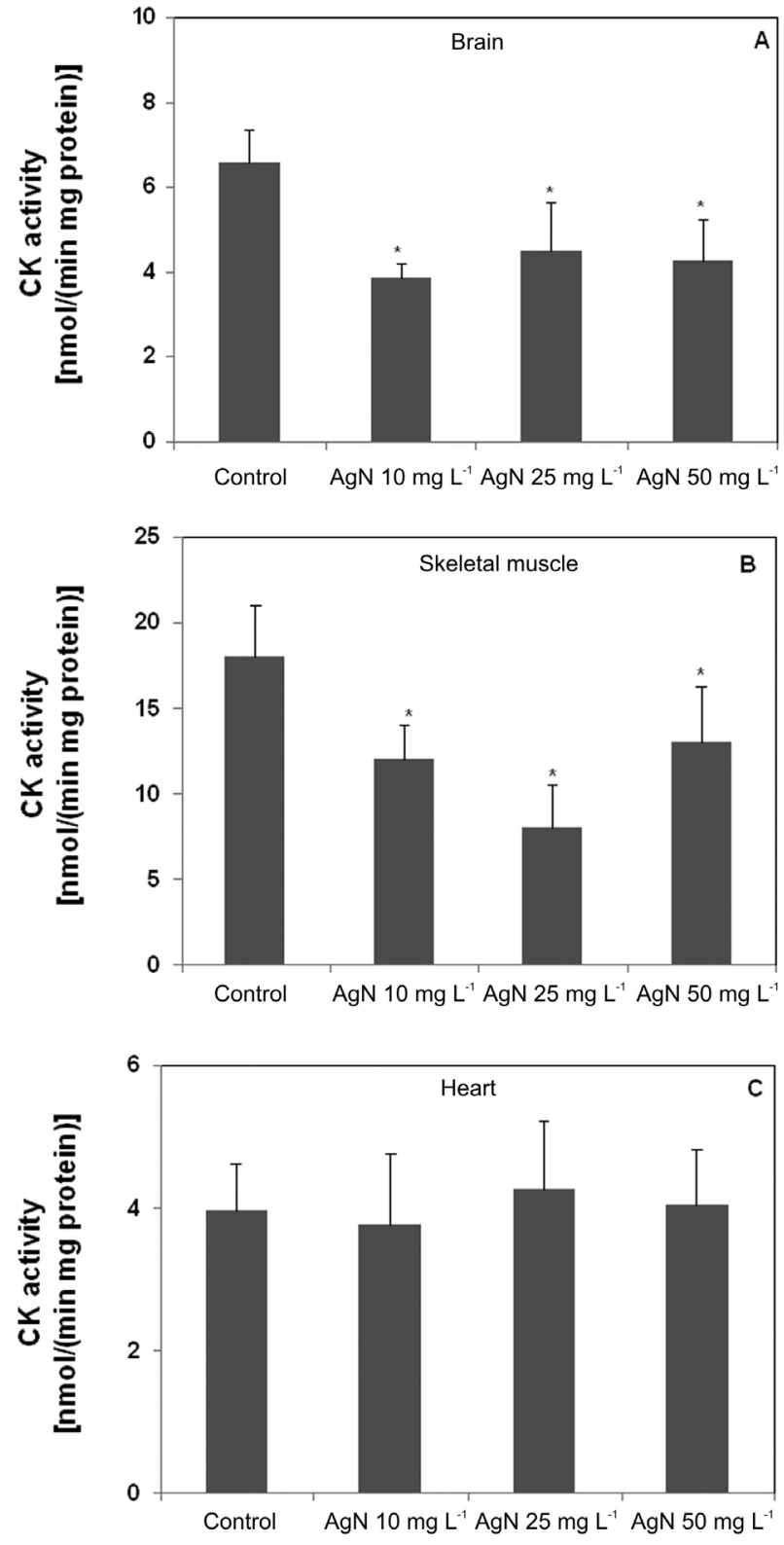

Figure 3. In vitro effect of silver nanoparticles $(\mathrm{AgN})$ on creatine kinase (CK) activity in brain (A), skeletal muscle (B) and heart (C) of rats. Values are expressed as mean \pm S.D., for five independent experiments performed in duplicate. Different from control; $* \mathrm{p}<0.05$ (One-way ANOVA followed by Tukey).

part of $\mathrm{AgN}$ mechanism of cytotoxicity that precedes mitochondrial perturbation ${ }^{38}$ since thiol-group containing proteins are abundant in the cell membrane. Evidence from the literature suggests that nanoparticles do not possess unique toxicity mechanisms.

Some studies have demonstrated the role of CK in normal muscle and brain function, tissues that are more susceptible to reduction of energy metabolism. We have recently showed that $\mathrm{CK}$ is inhibited in animal models of neuropsychiatry disorders, such as bipolar disorder ${ }^{41}$ and after electroconvulsive shock. ${ }^{42}$ Moreover, it has been widely shown that a decrease in CK activity is associated with a neurodegenerative pathway that results in neuronal loss. ${ }^{21-25}$ In skeletal muscle, CK is essential to maintain a high concentration of ATP, adequate to maintain ionic gradients and perform the cellular mechanical work. ${ }^{43}$ Inhibition of CK activity in skeletal muscle has been shown to lead to significant contractile abnormalities, as well as alterations in muscle cell size, tubular aggregates of sarcoplasmic reticulum membranes, mitochondrial volume and size and also of glycolytic capacity. ${ }^{44,45}$

\section{Conclusions}

In this work, we demonstrated that $\mathrm{AgN}$ inhibited brain and skeletal muscle $\mathrm{CK}$ in vitro. On the other hand, heart $\mathrm{CK}$ was not affected in vitro by $\mathrm{AgN}$. Further studies are important to evaluate whether other enzymes involved in metabolism are also affected by AgN. Moreover, the in vivo effect of $\mathrm{AgN}$ on energy metabolism is also being evaluated.

\section{Acknowledgments}

This work was supported by grants from Conselho Nacional de Pesquisa e Desenvolvimento (CNPq), Fundação de Apoio à Pesquisa Científica e Tecnológica do Estado de Santa Catarina (FAPESC), Coordenação de Aperfeiçoamento de Pessoal de Nível Superior (CAPES) and Universidade do Extremo Sul Catarinense (UNESC).

\section{References}

1. Ronconi, L.; Sadler, P. J.; Coord. Chem. Rev. 2007, 1633, 251.

2. Clarke, M. J.; Coord. Chem. Rev. 2002, 69, 232.

3. Thompson, K. H.; Orvig, C.; Dalton Trans. 2006, 761, 6.

4. Bosettia, M.; Masseba, A.; Tobine, E.; Cannasa, M.; Biomaterials 2000, 887, 23.

5. Soto, K. F.; Carrasco, A.; Powell, T. G.; Murr, L. E.; Garza, K. M.; Mater. Sci. Eng., A. 2006, 1421, 26.

6. Yoshimaru, T.; Suzuki, Y.; Inoue, T.; Niide, O.; Ra, C.; Free Radical Biol. Med. 2006, 1949, 40.

7. Frank, X.; Karnik, R.; Wang, A. Z.; Alexis, F.; LevyNissenbaum, E.; Hong, S.; Langer, R. S.; Farokhzad O. C.; Nano Today 2007, 14, 2.

8. Shahverdi, A. R.; Fakhimi, A.; Shahverdi, H. R.; Minaian, S.; Nanomedicine (N. Y., NY, U. S.) 2007, 168, 3.

9. Lee, K. S.; El-Sayed, M. A.; J. Phys. Chem. B. 2006, 19220, 110.

10. Lei, N.; CN Patent 1806886, 2006.

11. Park, J. W.; KR Patent 2006055256, 2006. 
12. Muangman, P.; Chuntrasakul, C.; Silthram, S.; Suvanchote, S.; Benjathanung, R.; Kittidacha, S.; Rueksomtawin, S. J.; Med. Assoc. Thai. 2006, 953, 89.

13. Chen, H. W.; Su, S. F.; Chien, C. T.; Lin, W. H.; Yu, S. L.; Chou, C. C.; Chen, J. J.; Yang, P. C.; FASEB J. 2006, 2393, 20.

14. Hussain, S. M.; Hess, K. L.; Gearhart, J. M.; Geiss, K. T.; Schlager, J. J.; Toxicol. In Vitro 2005, 975, 19.

15. Yacobi, N. R.; Phuleria, H. C.; Demaio, L.; Liang, C. H.; Peng, C.; Sioutas, C.; Borok, Z.; Kim, K.; Crandall, E. D.; Toxicol. In Vitro 2007, 1373, 21.

16. Braydich-Stolle, L.; Hussain, S.; Schlager, J. J.; Hofmann, M. C.; Toxicol. Sci. 2005, 412, 88.

17. Hussain, S. M.; Javorina, A. K.; Schrand, A. M.; Duhart, H. M.; Ali, S. F.; Schlager, J. J.; Toxicol. Sci. 2006, 456, 92.

18. Bessman, S. P.; Carpenter, C. L.; Annu. Rev. Biochem. 1985, 831, 54.

19. Schnyder, T.; Gross, H.; Winkler, H.; Eppenberger, H. M.; Wallimann, T.; J. Biol. Chem. 1991, 5318, 266.

20. Wallimann, T.; Wyss, M.; Brdiczka, D.; Nicolay, K.; Eppenberger, H. M.; Biochem. J. 1992, 21, 281.

21. Tomimoto, H.; Yamamoto, K.; Homburger, H. A.; Yanagihara, T.; Acta Neuropathol. 1993, 447, 86.

22. Hamman, B. L.; Bittl, J. A.; Jacobus, W. E.; Allen, P. D.; Spencer, R. S.; Tian, R.; Ingwall, J. S.; Am. J. Physiol. 1995, 1030, 269.

23. Gross, W. L.; Bak, M. I.; Ingwall, J. S.; Arstall, M. A.; Smith, T. W.; Balligand, J. L.; Kelly, R. A.; Proc. Natl. Acad. Sci. USA 1996, 5693, 93.

24. David, S. S.; Shoemaker, M.; Haley, B. E.; Mol. Brain Res. 1998, 276, 54.

25. Aksenov, M. Y.; Aksenova, M. V.; Butterfield, D. A.; Markesbery, W. R.; J. Neurochem. 2000, 2520, 74.

26. Jana, N. R.; Gearheart, L.; Murphy, C. J.; Chem. Commun. (Cambridge, U. K.) 2001, 617, 7.

27. Murphy, C. J.; Jana, N. R.; Adv. Mater. (Weinheim, Ger.) 2002, 80,14 .

28. Lowry, O. H.; Rosebrough, N. J.; Farr, A. L.; Randall, R. J.; J. Biol. Chem. 1951, 265, 193.
29. Hughes, B. P.; Clin. Chim. Acta 1962, 597, 7.

30. Sun, Y.; Gates, B.; Mayers, B.; Xia, Y.; Nano Lett. 2002, 165, 2.

31. Jiang, L. P.; Xu, S.; Zhu, J. M.; Zhang, J. R.; Zhu, J. J.; Chen, H. Y.; Prog. Inorg. Chem. 2004, 5877, 43.

32. Segala, K.; Dutra, R. L.; Oliveira, E. N.; Rossi, L. M.; Matos, J. R.; Paula, M. M. S.; Franco, C. V.; J. Braz. Chem. Soc. 2006, 1679, 17.

33. Wolosker, H.; Panizzutti, R.; Englender, S.; FEBS Lett. 1996, 274, 392.

34. Almofti, M. R.; Ichikawa, T.; Yamashita, K.; Terada, H.; Shinohara, Y.; J. Biochem. 2003, 43, 134.

35. André, N.; Science (Washington, DC, U. S.) 2005, 804, 6.

36. Elechiguerra, J. L.; Burt, J. L.; Morones, J. R.; CamachoBragado, A.; Gao, X.; Lara, H. H.; Yacaman, M. J.; J. Nanobiotechnol. 2005, 6, 3.

37. Jose, R. M.; Jose, L. E.; Alejandra, C.; Katherine, H.; Juan, B. K.; Jose, T. R.; Miguel, J. Y.; Nano Sci. Nano Technol. 2005, $2346,16$.

38. Chen, X.; Schluesener, H. J.; Toxicol. Lett. 2008, 1, 176.

39. Chappell, J. B.; Greviller, G. D.; Nature (London, U. K.) 1954, 930, 174

40. Kone, B. C.; Kaleta, M.; Gullans, S. R.; J. Membr. Biol. 1988, $11,102$.

41. Streck, E. L.; Amboni, G.; Scaini, G.; Di-Pietro, P. B.; Rezin, G. T.; Valvassori, S. S.; Luz, G.; Kapczinski, F.; Quevedo, J.; Life Sci. 2008, 424, 82.

42. Burigo, M.; Roza, C. A.; Bassani, C.; Feier, G.; Dal-Pizzol, F.; Quevedo, J.; Streck, E. L.; Neurochem. Res. 2006, 877, 31.

43. Kammermeier, H.; Basic Res. Cardiol. 1987, 31, 82.

44. Shoubridge, E. A.; Radda, G. K.; Biochim. Biophys. Acta 1984, $79,805$.

45. Van-Deursen, J.; Heerschap, A.; Oerlemans, F.; Ruitenbeek, W.; Jap, P.; Ter-Laak, H.; Wiering, B.; Cell. (Cambridge, MA, U. S.) 1993, 621, 74.

Received: July 11, 2008

Web Release Date: August 28, 2009 